\title{
The Influence of Western Countries' Sanctions on the Development of the Russian Exit Tourism
}

\author{
Ovcharov A. O. ${ }^{1}$, Ismagilova G. N. ${ }^{2}$, Ziganshin I. I. ${ }^{1} \&$ Rysayeva M. A. ${ }^{1}$ \\ ${ }^{1}$ Institute of Economics, Management and Law, Kazan, Russian Federation \\ ${ }^{2}$ Kazan Federal University, Institute of Management, Economics and Finance, Kazan, Russia \\ Correspondence: Ovcharov A. O., Institute of Economics, Management and Law, Kazan, Russian Federation.
}

Received: March 10, 2015 Accepted: March 31, 2015 Online Published: April 30, 2015

doi:10.5539/ass.v11n11p289 URL: http://dx.doi.org/10.5539/ass.v11n11p289

\begin{abstract}
The article is devoted to the influence of Western countries' sanctions on the current state of the Russian tourist market. The tourist services market of the period before sanctions is compared with its modern condition. The reasons of the exit tourism crisis and their connection with sanctions against Russia are analyzed.
\end{abstract}

Keywords: economic sanctions, Russian tourist market, tourist season of 2014, entrance tourism in Finland, dumping, ruble devaluation, crisis, bankruptcies of tour operators, consequences of sanctions on tourism

\section{Introduction}

The classical definition of sanctions associates them with the coercive measures of political or economic character, applied to a country, which is considered to violate international law. These measures are intended to force the object of sanctions follow a certain pattern of behavior corresponding to the international legal norms (Daoudi \& Dajani, 1983).

The forms of sanctions can be various - from boycotting certain events to complete prohibition of international trade of goods and services. The sanctions evolved from single "intimidation acts" in the $19^{\text {th }} \mathrm{c}$ (mainly in the form of sea blockades), to mass acts by the end of the $20^{\text {th }} \mathrm{c}-$ in 1970-1999 sanctions were applied 117 times (Братерский, 2009).

The sanctions imposed by the USA, EU and other countries on Russia in 2014 and the retaliatory food embargo by the RF are a grave confrontation of Russia and the West in the modern post-Soviet history. The first round of sanctions (March 2014) by the USA, EU, Australia, New Zealand and Canada implied travel bans and asset freezes for RF citizens included into special lists (the so called "EU list" and "US list"). Further expansion of sanctions led to curtailing projects with the Russian governmental bodies and commercial organizations in various spheres, such as military-technological cooperation, space sector, banking sphere, etc.

Tourist industry is no exception. Tourist flow from Russia to Europe has reduced, the risks of joint investment projects in hospitality industry have grown, the Russia's image for entrance tourism has worsened. The effect of economic sanctions in this sphere has increased due to two more negative factors - ruble devaluation and the fall of the leading players in the tourist market.

Besides, the humanitarian aspect of sanction policy should be taken into account. As a matter of fact, one of the ideas of the sanctions concept is in imposing the maximal harm on the people of the country under the sanctions. This is done to make the people more actively influence its government in order to change the social-economic and political conditions. In other words, sanctions finally worsen the condition of common people, not elites. Many of them are middle class people, who are the main consumers of tourist services. Sanctions lead to lowering the living standard of people, to degradation of social sphere and services, and the reduction of tourist trips and tourist expenses is a sign of such degradation.

Note that these two indicators (tourist trips and tourist expenses) are the key indicators of the development of the national and international tourism. There are a lot of research on statistical and econometric models allowing to study the connections between the trips characteristics and the influence of tourism on economy. A number of models analyze the impact of various factors on individual expenses (Brida \& Scuderi, 2013; Wang \& Davidson, 2010). These models allow to assess the influence of various demand variables on the general volume of tourist 
expenses. As a rule, all models use regression analysis for the qualitative assessment of interactions between variables.

The majority of individual consumption models view the level of expenses as a function of economic, social-demographic, psychological and other variables, connected with a trip (Chen \& Chang, 2012; Marcussen, 2011; Thrane \& Farstad, 2011). Besides, there is a class of models, estimating the probability of tourist expenses in case of choosing between the tourist services consumption and purchasing other goods (Alegre, Mateo, \& Pou, 2010; Saayman \& Saayman, 2006; Crouch, Oppewal, Huybers, Dolnicar, Louviere, \& Devinney, 2007). Finally, there are different models of tourist multiplier, based on Keynesian approach. According to Keynesian multiplier, the initial value of expenses draws a chain reaction, which leads to the multiple change of income, though reducing with each cycle. The larger the multiplier, the more significant the tourism contribution into the economy.

The results of statistical and econometric modelling to tourist trips and tourist expenses are used to estimate the condition and to predict the tourism development in different countries (Brida, Lanzilotta, Lionetti, \& Risso, 2010; Divisekera, 2010; Nicolau \& Más, 2005).

\section{Russian Tourism before Economic Sanctions: Successes and Risks}

During the modern period, the national market of tourist services has undergone several stages, which were characterized by the diverse influence of various risks on the functioning of tourist industry. If we consider 1992-2013 as the research period (since the beginning of market reforms till the beginning of sanction), it can be divided into three stages by the degree and character of risk factors influencing tourism.

The first stage (1992-2002) was characterized by the powerful impact of social-political and macroeconomic risk factors, which were due to the transition period and instable social-economic situation in the country. The main feature of that period is the lack of clear state policy in the sphere of exit and entrance tourism, the obsolescence of material-technical base of tourist sector and stagnation of investment activity.

The lack of attention towards tourist sector in the first years of reforms caused the mass reorientation of consumers from the internal to foreign tourist market. Exit tourism gradually became the most popular recreation sphere for the Russian citizens. Thus, in 1995 the volume of exit tourism was 2607 thousand trips, in $2002-$ 5044 thousand trips (Tourism and Tourist Resources in Russia, 2004).

Most popular were the tourist programs with reduced sets of services: "shuttle" business or "shop-tours", which provided accommodation and transportation only. As for the Russian tourist industry, it witnessed reduction of hotel chains and the number of tourists served.

The second stage (2002-2008) can be defined as "demand boom" in the tourist market, which was due to overcoming the crisis in the Russian economy and increasing the living standard. The share of tourist services, elastic on income, increased even under slow growth of real income of the population. Gradually the foreign turnover of tourist services increased, inflation slowed, and investment into tourist sector grew.

However, the "tourist boom" was mainly oriented towards exit sector. The low popularity of the Russian tourist-recreation zones was due to the poor development of the modern structure of health improvement and entertainment, to the high prices, seasonality of the Russian tourist products and lack of efficient marketing of different tourist programs.

The third stage (2009-2013) is the period of satisfying the consumers' demand in the tourist market, entering the world economic crisis and relatively rapid recovery.

The dynamics of the main economic indicators of the Russian tourist industry in the years before economic sanctions is shown in Table 1. Before the sanctions the Russian tourism was characterized by various and often controversial trends. On the one hand, positive changes occurred in the tourist sector of the Russian economy. Thus, the number of both independent hotels and world hotel chains increased (such brands as Hilton, Kempinski, Radisson SAS, Novotel, Park Inn and others actively entered the Russian market), their room capacity and loading soared. Many tourism indicators showed positive dynamics. According to UNWTO, in 2012 Russia was in the top ten world leaders in two indicators: tourist arrivals $\left(9^{\text {th }}\right.$ position) and tourist expenses $\left(5^{\text {th }}\right.$ position) (UNWTO Tourism Highlights Edition, 2014).

At the same time, the positive trend of tourist industry development in Russia have been always connected with risks due to the underdevelopment of the regional tourist infrastructure and terrorist threats, first of all, in the North Caucasus territories. That is indirectly confirmed by the data of the World Economic Forum: in 2013 
Russia held the $63^{\text {rd }}$ position by the competitiveness index in the sphere of tourism and travel out of 140 countries (Russia's general index was 4.16) (The Travel \& Tourism Competitiveness Report, 2013).

Table 1. Dynamics of tourism indicators in Russia

\begin{tabular}{|c|c|c|c|c|c|c|c|}
\hline Indicators & 2007 & 2008 & 2009 & 2010 & 2011 & 2012 & 2013 \\
\hline \multicolumn{8}{|l|}{ Share of tourism and travel industry in GDP, \%: } \\
\hline Direct & 1,4 & 1,4 & 1,5 & 1,4 & 1,3 & 1,3 & 1,4 \\
\hline Total & 5,8 & 5,7 & 6,3 & 5,8 & 5,6 & 5,6 & 5,8 \\
\hline $\begin{array}{l}\text { Number of foreign citizens entering Russia (non-CIS } \\
\text { countries, thousand people) }\end{array}$ & 8347 & 8551 & 8361 & 8266 & 9194 & 10175 & 10869 \\
\hline \multicolumn{8}{|l|}{ Including by the purpose of visit: } \\
\hline business & 2293 & 2945 & 2755 & 3035 & 3753 & 4058 & 3516 \\
\hline tourism & 2123 & 2168 & 2000 & 2025 & 2228 & 2430 & 2506 \\
\hline private & 2853 & 2389 & 2663 & 2174 & 2121 & 2483 & 3582 \\
\hline $\begin{array}{l}\text { Number of Russian citizens leaving Russia (non-CIS } \\
\text { countries, thousand people) }\end{array}$ & 18692 & 20464 & 21638 & 25487 & 29271 & 33142 & 38521 \\
\hline \multicolumn{8}{|l|}{ Including by the purpose of trips: } \\
\hline business & 1712 & 1614 & 1043 & 1133 & 1203 & 975 & 801 \\
\hline tourism & 9041 & 10822 & 9192 & 12231 & 14052 & 14816 & 17682 \\
\hline private & 6071 & 6072 & 9879 & 10188 & 11962 & 15141 & 17746 \\
\hline $\begin{array}{l}\text { Volume of paid services to the population, total, } \% \\
\text { including: }\end{array}$ & 100 & 100 & 100 & 100 & 100 & 100 & 100 \\
\hline Tourism & 1,6 & 1,8 & 1,7 & 2,0 & 2,0 & 2,0 & 2,1 \\
\hline Health improvement & 1,4 & 1,4 & 1,4 & 1,2 & 1,2 & 1,3 & 1,0 \\
\hline Services of hotels and other means of accommodation & 2,7 & 2,6 & 2,4 & 2,3 & 2,3 & 2,3 & 2,3 \\
\hline \multicolumn{8}{|l|}{ Indexes of prices for tourist services $(\%$, December to } \\
\hline \multicolumn{8}{|l|}{ December of the previous year): } \\
\hline Services of foreign tourism & 106,2 & 122,9 & 107,8 & 100,2 & 105,4 & 103,4 & 109,1 \\
\hline Health improvement services & 115,6 & 121,2 & 109,5 & 105,4 & 109,0 & 105,9 & 105,7 \\
\hline Excursion services & 115,6 & 122,3 & 110,1 & 104,8 & 106,5 & 108,8 & 115,0 \\
\hline \multicolumn{8}{|l|}{ Main indicators of accommodation means: } \\
\hline Number of hotels & 5917 & 6774 & 7410 & 7866 & 8406 & 9316 & 9855 \\
\hline Accommodated, thousand people & 22125 & 24742 & 21175 & 24026 & 27112 & 30235 & 31661 \\
\hline Number of Health improvement organizations & 2118 & 2147 & 1997 & 1945 & 1959 & 1905 & 1841 \\
\hline Accommodated, thousand people & 6071 & 6356 & 5774 & 5674 & 5733 & 5751 & 5675 \\
\hline
\end{tabular}

Source: Russian Statistical Agency, World Tourism and Travel Council (WTTC) (Ajupov, Mishina, \& Ivanov, 2014)

That is four positions worse than in the previous year. The natural and cultural-historic sub-ratings of Russia are quite high, but its security level ( $113^{\text {th }}$ position) worries both the international experts and foreign tourists. Thus, according to the official Russian statistics, in 2012 not a single foreign person stayed in the hotels of two Caucasus republics (Chechen and Ingush), while more than $2 \mathrm{mln}$ foreign tourists visited Moscow and Saint Petersburg.

\section{Sanctions and Tourism: Trends of Tourist Season 2014}

Imposing economic sanctions on Russia as a result of conflict escalation in the Eastern Ukraine led to the sharp decrease of the tourist flow from RF to EU countries in 2014. The greatest reduction of the tourist flow was witnessed by such European destinations as Finland, Greece, Austria, Czech Republic (Table 2) (Falk, 2013).

Finland is an example of the country facing a sharp decrease of entrance tourism from Russia. In 2013 Finland was in the top 5 countries most popular with the Russian tourists, while in 2014 it was the $13^{\text {th }}$. In January-September 2014 it was visited by only 295500 Russian tourists, which is 491659 people less than in the same period of 2013. The number of visa applications from the Russians decreased twice (from $1 \mathrm{mln}$ applications in 2013 to 500 thousand in 2014), the number of nights spent by the Russian tourists in the Finnish hotels decreased, and the Russian tourists spent less money in Finland (Table 3) (Falk, 2013; Jones, Herbert, Hudspeth, Soni, Tarry, \& Walton, 2009; Furmanov, Balaeva, \& Predvoditeleva, 2012). 
Table 2. Dynamics of European countries' visits by the Russian tourists in the first 9 months of 2013 and 2014

\begin{tabular}{cccc}
\hline \multirow{2}{*}{ Country } & \multicolumn{2}{c}{ Tourist arrivals from Russia, in 9 months (January-September), people } \\
\cline { 2 - 4 } & 2013 & 2014 & $2013 / 2014, \%$ \\
\hline Greece & 1892211 & 976594 & $-48,4$ \\
Spain & 887191 & 882541 & $-0,5$ \\
Finland & 787159 & 295500 & $-62,4$ \\
Germany & 638193 & 632357 & $-0,9$ \\
Italy & 605482 & 635396 & $+4,9$ \\
Cyprus & 494702 & 491595 & $-0,6$ \\
Bulgaria & 478829 & 481209 & $+0,4$ \\
Czech Republic & 355475 & 321661 & $-9,5$ \\
Ukraine & 333462 & 82845 & $-75,2$ \\
France & 298029 & 292670 & $-1,8$ \\
Montenegro & 233672 & 235266 & $+0,7$ \\
Austria & 209277 & 182459 & $-12,8$ \\
Switzerland & 159189 & 166633 & $+4,7$ \\
Great Britain & 143862 & 143111 & $-0,5$ \\
\hline
\end{tabular}

Source: Federal Agency on Tourism of the RF Ministry of Culture.

Table 3. Dynamics of statistical indicators of tourist sector development in Finland due to the Russian entrance tourism in 2013-2014

\begin{tabular}{lcc}
\hline Indicator & 2013 & 2014 \\
\hline Number of tourists trips (people) & 787159 (January-September) & 295500 (January-September) \\
Traffic on the Russian-Finnish border & 3893621 (January-April) & 3685370 (January-April) \\
$\begin{array}{l}\text { Number of nights in the Finnish hotels (thousand) } \\
\text { Number of applications for visa from the Russian (1 }{ }^{\text {st }} \text { half } \\
\text { of the year) }\end{array}$ & 929 & 739 \\
$\begin{array}{l}\text { Average price for the rent of cottages (Euros) } \\
\text { Number of trips by the Russian by "Allegro" trains } \\
\text { (thousand) }\end{array}$ & 8400 mln applications \\
Average spending of a Russian tourist (Euros) & 400 & 1400 \\
\hline
\end{tabular}

Sources: Federal Agency on Tourism of the RF Ministry of Culture, European Commission on Tourism (ECT), National Center for Tourism "Visit Finland".

The analysis allowed to highlight four groups of causes of crisis in the Russian exit tourism market:

1. Ruble devaluation and, as a consequence, a sharp fall of demand for exit tours and consuming power of the national currency in general;

2. High competition and many years of damping by the leading players in the tourist market, which led to a series of bankruptcies of tour operators and high tension in the organized tourism market;

3. Economic sanctions and negative political-economic situation both in Russia and in its relations with the world community (annexing the Crimea, crisis in the Ukraine, expulsion of Russia from G8, prohibition of foreign trips to the personnel of security, defense and law enforcement agencies, worse attitude to the Russian tourists).

4. Other causes (outburst of inflation fears, reduction of investment into tourist industry, introduction of the obligatory fingerprinting procedure for the Russians applying for Schengen visas, increasing state duties for issuing foreign passports).

The detailed analysis of the above causes allowed to reveal the problem aspects of the sector and to make a complex evaluation of the present tense situation in the Russian tourism market.

(1). Ruble devaluation.

The purchasing capacity of the national currency is one of the most important economic indicators, which shows the amount of goods and services an average consumer can buy for a certain sum of money. It is well known that the fluctuations of the national currency rates can negatively influence the international tourist arrivals. 
The Tsentrobank's transition to the floating rate and inflation targeting shows that the Russian ruble rapidly becomes cheaper in relation to the foreign currency. Nowadays there is a trends to weakening the national economy and, consequently, decreasing the purchasing capacity of the RF citizens. Import goods become more expensive, while the salaries remain the same (many prediction suggest, the real income of the population will decrease in 2015). Not only cars and electronic devices become more expensive. The majority of the population will not be able to afford a holiday abroad - it is too expensive to spend currency.

The dynamics of foreign trips by the Russian tourists (Table 1) is an indicator of the population's purchasing capacity and shows the fall and rise of tourist activity of the population.

Devaluation has dramatically hit the Russian tourists, mainly in the European destinations, which has been the most rapidly developing tourist exit market in the few recent years. In 2014 sales of tours to Europe decreased by $30-50 \%$, according to the Russian tourist operators. Thus, according to the Russian Union of Tourist Industry (RUTI), in September 2013 the online booking systems showed no tickets for the New Year trips to Europe. In the mid November 2014, plane tickets to Europe for the New Year holidays were available.

The group of Christmas tours to Scandinavia shows the positive dynamics of demand only for the short-term (3-4 days) and combined tours with visits of two Scandinavian capitals (Helsinki and Stockholm). To prove the positive dynamics of consumer demand for short-term tours to Finland and Scandinavia, we present the tours, their prices, and degree of availability, by the Saint Petersburg tour operator "Bon Tour" (Table 4).

Table 4. Cruise tours in Scandinavia and the Baltics by "Bon Tour" firm

\begin{tabular}{|c|c|c|c|c|c|}
\hline Tour & Route & Transport & Price, rubles & Date & Status \\
\hline $\begin{array}{c}\text { Finland - Sweden, } \\
3 \text { days }\end{array}$ & $\begin{array}{c}\text { Saint Petersburg - Helsinki - } \\
\text { Turku - Stockholm }\end{array}$ & Bus + ferry & 6614 & 02.01 .15 & Booked \\
\hline $\begin{array}{c}\text { Finland - Sweden, } \\
4 \text { days }\end{array}$ & $\begin{array}{l}\text { Saint Petersburg - Helsinki - } \\
\text { Turku - Stockholm }\end{array}$ & Bus + ferry & 9259,6 & 02.01 .15 & 6 vacancies \\
\hline $\begin{array}{c}\text { Finland - Sweden, } \\
5 \text { days }\end{array}$ & $\begin{array}{l}\text { Saint Petersburg - Helsinki - } \\
\text { Turku - Stockholm }\end{array}$ & Bus + ferry & 14881,5 & 06.01 .15 & Booked \\
\hline
\end{tabular}

Source: official web-site of "Bon Tour" firm

The record low ruble rate has logically reduced the tourist flow from Russia to Finland. At the same time, the Finns grow more interested in tourism in Russia, as one Euro now costs 65 rubles instead of 40. The Russian companies offer tours at moderate prices, three nights at hotels can be purchased at a price of two, which proves that Finnish tourists are welcome in Russia.

Nevertheless, the promotion programs of Finnish tourism in the Russian market will continue functioning. The Finnish Agency on Tourism is planning to allocate about 600 thousand euros for their promotion in Russia.

(2). Damping and bankruptcy of tour operators.

Under tough competition, many participants of the tourist market use various tactical and strategic techniques (price discounts, season sales, etc.), including unfair ones, like damping. In the general sense, damping is selling goods and services at prices lower than cost value. Damping is actively used in the tourist market. The large tour operators, which became bankrupt later ("Neva", "Yuzhniy krest", "Labirint"), used damping schemes.

The point, which was followed by a series of bankruptcies of the leading tour operators, occurred at the peak of vacation period (July-September 2014). During that period, more than ten tour operators announced stoppage of their functioning. Simultaneously, the trend of the national currency devaluation became distinct. The US dollar grew from 35 to 39 rubles per dollar, and the euro - from 47 to 50 rubles.

The list of tour operators which went bankrupt in 2014, an unprecedented phenomenon in the modern Russian tourism, is shown in Table 5.

The data shown in Table 5 prove that the reasons for bankruptcy of all tour operators are mainly the same. The main reasons are the general economic and political situation in the country, selling products at artificially reduced prices due to the low demand, and the cash gaps. Another factor was the undercover prohibition of foreign trips to the personnel of security, defense and law enforcement agencies (about $10 \%$ of the market), who had spent vacations abroad and spent a lot of money there. 
Table 5. The list of tour operators, which went bankrupt in 2014

\begin{tabular}{|c|c|c|c|c|}
\hline $\begin{array}{l}\text { Name of } \\
\text { tour } \\
\text { operator }\end{array}$ & $\begin{array}{c}\text { Date of } \\
\text { stoppage of } \\
\text { functioning }\end{array}$ & $\begin{array}{l}\text { Number of tourists who } \\
\text { suffered from bankruptcy, } \\
\text { thousand people }\end{array}$ & Insurance company & Causes of bankruptcy \\
\hline $\begin{array}{l}\text { Neva } \\
\text { Travel }\end{array}$ & 16.07.2014 & 24 & $\begin{array}{l}\text { "Voskhozhdeniye" } \\
\text { Insurance Company }\end{array}$ & $\begin{array}{l}\text { Unstable ruble rate, unstable economic } \\
\text { and political situation in the country, } \\
\text { damping }\end{array}$ \\
\hline $\begin{array}{l}\text { Roza } \\
\text { Vetrov, } \\
\text { Mir }\end{array}$ & 25.07 .2014 & 1,5 & $\begin{array}{l}\text { "BIN-Strakhovaniye", } \\
\text { "Ingosstrakh" Open } \\
\text { Corporation }\end{array}$ & $\begin{array}{l}\text { Unstable ruble rate, unstable economic } \\
\text { and political situa-tion in the country }\end{array}$ \\
\hline Ideal Tur & 01.08 .2014 & 20 & $\begin{array}{l}\text { "VSK" Open } \\
\text { Corporation }\end{array}$ & $\begin{array}{l}\text { Unstable ruble rate, unstable economic } \\
\text { and political situa-tion in the country }\end{array}$ \\
\hline Labirint & 02.08 .2014 & 65 & $\begin{array}{l}\text { "Voskhozhdeniye" } \\
\text { Insurance Company, } \\
\text { "VSK" Open } \\
\text { Corporation }\end{array}$ & $\begin{array}{l}\text { Unstable ruble rate, unstable economic } \\
\text { and political situation in the country, } \\
\text { recommendations not to leave the } \\
\text { country for the personnel of security, } \\
\text { defense and law enforcement agencies, } \\
\text { damping }\end{array}$ \\
\hline $\begin{array}{l}\text { Solveks } \\
\text { Turne }\end{array}$ & 08.09.2014 & 17,8 & $\begin{array}{l}\text { "Voskhozhdeniye" } \\
\text { Insurance Company, } \\
\text { "VSK" Open } \\
\text { Corporation }\end{array}$ & $\begin{array}{l}\text { Decrease of demand for tourist } \\
\text { products after bankruptcy of the } \\
\text { leading tour operators, damping, } \\
\text { unstable economic and political } \\
\text { situation in the country }\end{array}$ \\
\hline $\begin{array}{l}\text { Yuzniy } \\
\text { krest }\end{array}$ & 10.09 .2014 & 29 & RESO-Garantiya & $\begin{array}{l}\text { Decrease of demand for tourist } \\
\text { products after bankruptcy of the } \\
\text { leading tour operators, damping }\end{array}$ \\
\hline Versa & 15.09 .14 & 15 & $\begin{array}{l}\text { Avesta, VSK, } \\
\text { Avangard Polis }\end{array}$ & $\begin{array}{l}\text { Decrease of demand for tourist } \\
\text { products after bankruptcy of the } \\
\text { leading tour operators }\end{array}$ \\
\hline
\end{tabular}

(3). Economic sanctions and negative political-economic situation.

The negative political-economic situation in Russia, which had resulted from economic sanctions, together with ruble devaluation, damping wars and bankruptcy of the large players of the sector, deepened the crisis of the tourism industry.

The USA, Great Britain, Germany, Latvia, Norway, Poland, France, Czech Republic, Sweden - these are just a few countries which reduced cooperation with Russia in the key economic sectors due to the imposed sanctions. Brazil, China, Mexico, Cyprus, South Korea, Turkey have not imposed the sanctions against Russia, showing their independency.

What is the current and future influence of anti-Russia sanctions on the tourist market? All leading players, together with "Rosturizm", admit that the EU and US sanctions influenced the crisis in the tourism industry. It produced the effect of overall mistrust, as the business conditions are changing, and requirements of foreign partners, banks and insurance companies towards market participants become tougher. The spirits of the consumers are also influenced by the sanctions. When people watch the negative news, it has more impact on tourism than on other sectors. For example, an airplane crush causes a $20 \%$ reduction of air travel around the world during a week or two.

Further sanctions against Russia can have the following consequences for the Russian and foreign participants of tourism industry:

- Stricter conditions for obtaining EU visas.

- Difficulties in using plastic cards abroad (Visa and Master Card).

- Reconstruction of the Russian tourist sector towards internal tourism (increase of the share of internal trips, informational promotion of internal trips and development of Crimea infrastructure).

(4). Other reasons.

Aggravation of the overall economic situation in Russia, introduction of the obligatory fingerprinting procedure for the Russian tourists applying for Schengen visas, the coming increase of state duties for issuing foreign passports - all this limits the active functioning of the Russian tourist market. 
The second half of 2014 showed the trend to redistribute the demand from European destinations towards visa-free resorts of Turkey and Egypt (+20-25\%), which represent the lowest price segment. Those who could afford trips to Italy will now choose trips to Anatolia or Egyptian resorts. Thus, in December 2014 weeklong tours from Moscow to Egypt were offered at 30-50 thousand rubles, while similar trips to Prague cost 64-100 thousand rubles.

One should pay attention to one more circumstance, not negative for the tourist market in general, but hindering the development of various forms of organized tourism. The bankruptcies of tour operators, which had been considered reliable, undermined the trust of citizens towards the work of tour operators and agents. Many Russian tourists had to stop using the services of tourist agencies and begin organizing their own vacations. This is promoted by the simple technological means for independent booking of hotels and flights (Oktogo.ru, Booking.com, Agoda.ru, Hotels.com, etc.). Together with the above-mentioned problems, this circumstance cannot but worry the leading players in the market. The research of consumer preferences of the Russians confirm that the number of independent tourists grow year by year. According to the international research company Synovate Comcon, in the first half of 2010 24.9\% of tourists from cities with population over $1 \mathrm{mln}$ people admitted that they do not use services of tourist agencies. In the first half of $201228.8 \%$ of tourists admitted that fact, and in the first half of $2014-31.9 \%$ (about 9 mln people) (Brida, Lanzilotta, Lionetti, \& Risso, 2010).

According to the Association of the Russian tour operators, the introduction of the obligatory fingerprinting procedure for the Russian tourists applying for Schengen visas, planned for 2015, can lead to $50-60 \%$ decrease of the Russian tourist flow and thus ad to the list of negative effects for the development of tourist sector.

The procedure suggests that all citizens applying for a visa should be fingerprinted once in 5 years. This requirement is likely to cause financial losses of the European countries due to the reduction of the tourist flow from Russia. Thus, in Greta Britain before 2008 (before introduction of fingerprinting) the annual share of the Russian entrance tourism was $9 \%$. Immediately after introduction of fingerprinting, the tourist flow into Great Britain decreased by $50 \%$. Accordingly, the introduction of fingerprinting all over EU will lead to the sharp reduction of the Russian demand for European tours. The hardest blow will be given to those countries, in which the Russian tourists are a significant engine of the economy. One of the examples is Finland, where Russian tourists spend more money than tourists from other countries (1,3 bln euros last year).

As for the Russian tourist business, the new procedure will strike the tour operators specializing in European destinations, especially the "niche" tour operators offering one or two countries. Tourists from provincial regions may also have hardships with the technical ability to undergo the fingerprinting procedure. As a result, the majority of these tourists will go to visa-free countries or will wait until the visas are abolished. One more factor, hindering the growth of tourist flow, is the coming two-fold increase of state duties for issuing biometric foreign passports, from 2500 to 3500 rubles.

Thus, 2014 was a hard year for the Russian tourist market. If the conflict with the West prolongs (anti-Russia sanctions are prolonged) and the ruble devaluation continues, we should expect further recession in the exit tourism market. Accordingly, the key task for the increase of the Russian tourist market stability is transition to import substitution. In this context, it means reorientation of the Russian tourist complex from the exit to entrance tourism. This task is very complex, but it can be fulfilled if a well-planned and goal-oriented policy is implemented. Investment should be activated in the form of direct and portfolio investment. This can become possible if the general flow of the capital from the Russian economy ceases. Under sanction this is hard to achieve, that is why nowadays investments can come from the internal sources only, with the mechanisms of state-private partnership. Tourist agencies should immediately begin work on forming, improving and diversification of the tourist products, connected with the various internal tourism programs. These programs can be popular, if the hotel and transportation network is developed and modernized not only in Moscow and Saint Petersburg, but in the Russian regions. The Russian regions should be viewed by the Russian tourists as zones favorable for all kinds of tourism. By the "price-quality" criterion, they should be no worse than world tourist centers. Thus, great attention should be paid to the formation of the positive tourist image of the Russian regions, supported by the particular action of the state and business for the development of tourist infrastructure in those regions. In that case Russia will be able to use the main competitive advantage - the natural and sociocultural contrasts which allow to develop all kinds of tourism in various places and in all seasons.

\section{References}

Ajupov, A. A., Mishina, M. S., \& Ivanov, M. E. (2014). Method of valuation of financial factors influencing the implementation of liquidity risk for leasing companies. Mediterranean Journal of Social Sciences, 5(24), 
154-159.

Alegre, J., Mateo, S., \& Pou, L. (2010). An analysis of households' appraisal of their budget constraints for potential participation in tourism. Tourism Management, 31(1), 45-56.

Brida, J. G., \& Scuderi, R. (2013, April). Determinants of tourist expenditure: a review of microeconometric models. Tourism Management Perspectives, 6, 28-40.

Brida, J. G., Lanzilotta, B., Lionetti, S., \& Risso, W. (2010). The tourism-led growth hypothesis for Uruguay. Tourism Economics, 16(3), 765-771.

Chen, C. M., Chang, K. L. (2012). The influence of travel agents on travel expenditures. Annals of Tourism Research, 39(2), pp. 1258-1263.

Crouch, G. I., Oppewal, H., Huybers, T., Dolnicar, S., Louviere, J. J., \& Devinney, T. (2007). Discretionary expenditure and tourism consumption: Insights from a choice experiment. Journal of Travel Research, 45(3), 247-258.

Daoudi, M. S., \& Dajani. M. S. (1983). Economic Sanctions: Ideals and Experience. Boston: Routledge \& Kegan Paul.

Divisekera, S. (2010). Economics of tourist's consumption behaviour: some evidence from Australia. Tourism Management, 31(5), 629-636.

Falk, M. (2013). The sensitivity of winter tourism to exchange rate changes: Evidence for the Swiss Alps. Tourism and Hospitality Research, 13(April), 101-112.

Furmanov, K., Balaeva, O., \& Predvoditeleva, M. (2012). Tourism flows from the Russian Federation to the European Union. Anatolia: An International Journal of Tourism and Hospitality Research, (March), 17-31.

Jones, P., Herbert, D., Hudspeth, S., Soni, S., Tarry, C., \& Walton, T. (2009). Impact of the Global Recession on the Hospitality and Tourism Industry. Tourism and Hospitality Research, 9(October), 363-367.

Marcussen, C. H. (2011). Determinants of tourist spending in cross-sectional studies and at Danish destinations. Tourism Economics, 17(4), 833-855.

Nicolau, J. L., \& Más, F. J. (2005). Heckit modelling of tourist expenditure: evidence from Spain. International Journal of Service Industry Management, 16(3), 271-293.

Saayman, A., \& Saayman, M. (2006). Sociodemographics and visiting patterns of arts festival in South Africa. Event Management, 9(4), 211-222.

The Travel \& Tourism Competitiveness Report. (2013). Retrieved December 19, 2014, from http://www3.weforum.org/docs/WEF_TT_Competitiveness_Report_2013.pdf

Thrane, C., \& Farstad, E. (2011). Domestic tourism expenditures: the non-linear effects of length of stay and travel party size. Tourism Management, 32(1), 46-52.

Tourism and Tourist Resources in Russia. (2004). Statistical Handbook. Retrieved from http://www.gks.ru/bgd/regl/b04_42/IssWWW.exe/Stg/d010/i010040r.htm

UNWTO Tourism Highlights Edition. (2014). Retrieved December 19, 2014, from http://www.e-unwto.org/content/r13521/fulltext.pdf

Wang, Y., \& Davidson, M. (2010). A review of micro-analyses of tourist expenditure. Current Issues in Tourism, 13(6), 507-524.

Братерский, М. В. (2009). Торгово-экономические санкции: эффективность, цена, проблемы использования. Безопасность Евразии, 2(36), 335-347.

\section{Copyrights}

Copyright for this article is retained by the author(s), with first publication rights granted to the journal.

This is an open-access article distributed under the terms and conditions of the Creative Commons Attribution license (http://creativecommons.org/licenses/by/3.0/). 